\title{
Competing for Coffee Space: Development-Induced Displacement in the Central Highlands of Vietnam*
}

\author{
Sylvie Doutriaux and Charles Geisler \\ Department of Development Sociology \\ Cornell University \\ Gerald Shively \\ Department of Agricultural Economics \\ Purdue University
}

\begin{abstract}
Vietnam has emerged as the world's second largest producer of coffee. The benefits of this expanding coffee economy are substantial but not universal; their distribution follows ethnic lines despite government commitment to equalize welfare. Focusing on Dak Lak Province in Vietnam's Central Highlands, we investigate this commercial transformation and the "competition for coffee space" that it has occasioned. Combined ethno history and household income analyses suggest markedly different benefits between native and non native ethnic groups, despite generally larger landholdings among the former. We interpret these finding through the conceptual lens of in situ development induced displacement.
\end{abstract}

Vietnam's successful entry into highland coffee production has challenged the coffee economies of other countries. In 1987, thirty countries produced greater quantities of coffee than Vietnam (Fortunel 2000:7); today, Vietnam is second only to Brazil in world coffee production. Vietnam held 1.2 percent of the world coffee market in 1989 and 12.4 percent ten years later (Luong and Tauer 2006:49). This surge in production has spawned interest in the fate of producers in such coffee strongholds as Colombia, Indonesia, Mexico, Ethiopia, Guatemala, Côte d'Ivoire and Uganda. Considerably less attention has been directed, however, to the impact of coffee expansion on ethnic minorities within Vietnam.

The present analysis seeks to remedy this inattention. Focusing on coffee production in Dak Lak Province in Vietnam's Central Highlands, we investigate whether this commercial transformation has advanced equality among ethnic groups in a socialist society committed to the

* Direct correspondence to Sylvie Doutriaux, sbd7@cornell.edu. This research was partially supported by the Office of Agriculture and Food Security, Bureau for Global Programs, U.S. Agency for International Development, under the terms of the SANREM CRSP award No. PCE A 009800019 00. The Mario Einaudi Center for International Studies at Cornell University also provided valuable support for field research in Vietnam. The authors appreciate the assistance of anonymous reviewers as well as Dang Thanh Ha (Nong Lam University), Steven Kyle and Lindy Williams (Cornell University) for their valuable insights as the paper developed. 
equalization of wealth and welfare. From a practical standpoint, this topic is of interest because, unlike so many socialist countries in the post-Soviet period, Vietnam has enjoyed unprecedented prosperity, due in part to its coffee exports. But along with modernization and ascendance in the world coffee market there may be emerging ethnic inequalities at odds with Vietnam's prevailing social doctrines. Although more than one ethnic group has enjoyed the overall benefits of coffee production, the incomes derived therein are markedly different between groups.

There are theoretical dimensions to this disparity of much interest to sociology and other disciplines. These are captured by recent discourses on development-induced displacement (DID), on internally displaced persons (IDPs), and more generally on social exclusion. Most DID research associates human dislocation with mega projects, which refers to major infrastructural works or to land use interventions such as land reform, urban renewal, or the installation of national parks or industrial parks that resettle local residents beyond the development footprint (Cernea and McDowell 2000; Vandergeest, Idahosa and Bose 2007). Social exclusion research similarly focuses attention on displacement within nation states (e.g., Saith 2001; Sen 2000) but allows for "displacement" from social capital and social security that induce poverty and may or may not entail spatial uprooting. Combined, DID and social exclusion theory draw needed attention to a range of public policies that, intended or not, advance some groups and displace others. This displacement has material consequences but is not always spatially evident.

Agricultural commodity booms are transforming the lowlandhighland relations of Vietnam (Henin 2002; Sikor and Pham 2005) as well as neighboring states such as Indonesia (Li 2002; Potter 2001), Cambodia (Paterson 1997), and Laos (Thapa 1998). In the highlands of Vietnam, massive agricultural development is occurring that privileges some ethnic groups over others. Groups which, with government encouragement, have moved to the Highlands from coastal zones in large numbers are now the ethnic majority. Those indigenous to the Highlands are of distinctly different ethnic origin and have in the past been targeted by government integration and assimilation efforts (Fortunel 2000). ${ }^{1}$ Understanding the DID, which the latter now face, requires greater attention to social exclusion and its

\footnotetext{
${ }^{1}$ In addition, the authorities of Dak Lak province and increasingly the national government are recognizing the land problem; forest land has been transferred to ethnic minority groups under several programs since 1999.
} 
consequences on income and other welfare measures. Specifically, research must move beyond the spatially referenced, forced migration framework, even where its within-state presence is conceded, to include in situ dispossession of property rights, welfare, and cultural identity (Feldman, Geisler, and Silberling 2003). In the absence of this approach, it is tempting to uncritically see the ethnic collateral damage of "agricultural modernization" as a naturalized, market-mediated transformation that is in no way problematic.

We employ a dual methodology in investigating the in situ displacement of selected ethnic groups in the Vietnam Highlands. First, we use ethno-history to establish the property rights, welfare conditions, and identity markers of Highland residents prior to the rapid diffusion of coffee production. We trace the spread of coffee culture during and after colonial times and inform this history with accounts of growing ethnic differentiation. We then turn attention to the recent coffee boom, the movement of ethnic majority Vietnamese, or Kinh, to the Central Highlands zone, and the discourses comparing them favourably to the dominant Highland minority, or Ede. Subsequent to our use of ethno-history, we use data from a 2003 survey of 209 smallholder coffee farmers to investigate DID using statistical techniques, including regression analysis, to compare coffee income among the Kinh and the Ede. We use these rather unique data to demonstrate how farm size, a principal source of household income and a function of government land policy, affects the Kinh and Ede differently. Although many Ede have undoubtedly benefited either directly or indirectly from the growth of Vietnam's coffee economy, many others have not; and a large number have been uprooted in place. Simply put, the Ede have gained title but lost ground. We conclude with commentary on how competition between native and non-native ethnic groups in Vietnam's Central Highlands might be managed differently to reduce rather than heighten ethnic inequalities and DID.

\section{A Brief Ethno-History ${ }^{2}$}

Coffee was brought to Indochina in the early $19^{\text {th }}$ Century by missionaries (Robequain 1939) and, by the 1890s, was cultivated in plantations by the French (Salemink 2003). Under colonial rule, the French confiscated land of highland populations and cleared forests to establish coffee and rubber for export. Despite significant earnings,

\footnotetext{
${ }^{2}$ For a fuller explanation of ethno history, see Burawoy et al. (2000).
} 
coffee proved more difficult to grow than crops such as lowland rice (Le Domaine Colonial Français 1929) and did not rank among top exports.

In the 1920s, Indochina's economy entered a growth phase (Brocheux and Hémery 2001), and colonists sought fertile lands beyond populated regions. Vast colonization zones were opened in the Highlands. The center of this growth in coffee culture was Dak Lak Province in the Central Highlands (see Figure 1), where indigenous culture was markedly different from that of the coastal lowlands.

Dependable labor became an immediate barrier to Highland coffee expansion. The French adopted a paternalistic and protective attitude towards the Ede (Fortunel 2000), but considered them "unstable" and not well suited to the plantation labor. In contrast, the Kinh were seen as loyal and assiduous paddy cultivators and gradually came to be favored over the "land-wasteful, unpredictable and lazy minorities." Shortly after World War II, the colonial administration encouraged the Kinh to move to the highlands to set a good example and to "form the nucleus of future Vietnamese populations of the Southern Montagnard countries" (Dournes 1980:13).

Traditionally, the Ede enjoyed a considerable degree of autonomy visà-vis the Vietnamese. Ede society had little or no supra-village structure, being organized around the basic elements of family, longhouse, and village in descending order of importance (Schrock 1966). The longhouse was the most important corporate kin group, consisting of one or more extended families in the same lineage. The members of a particular longhouse often worked in the same fields and shared food. Land was communally owned; a village's property included cultivated and uncultivated land, forest and streams, which were considered ancestral possessions and belonged to the village land guardian. Village members had usufruct rights over land but no ownership rights. The main economic activities of the Ede were subsistence swidden production of rice, supplemented by hunting, fishing and gathering. Ede also cultivated secondary crops in gardens and raised animals. Mutual assistance and reciprocity were widespread (Dang 2003).

Colonial rule brought a first blow to traditional Ede social organization and politico-economic make-up: the Ede tradition of swidden tenure and production was looked down upon and in certain areas farmers were forced to become sedentary. Nonetheless, until Vietnam's reunification in 1975, traditional Ede society retained many of its characteristics, such as the land tenure system and customary law practices. Moreover, most of the forest and agricultural land in the region still fell under the control and traditional management of Highland communities (Dao 2000; Hickey 1982). 


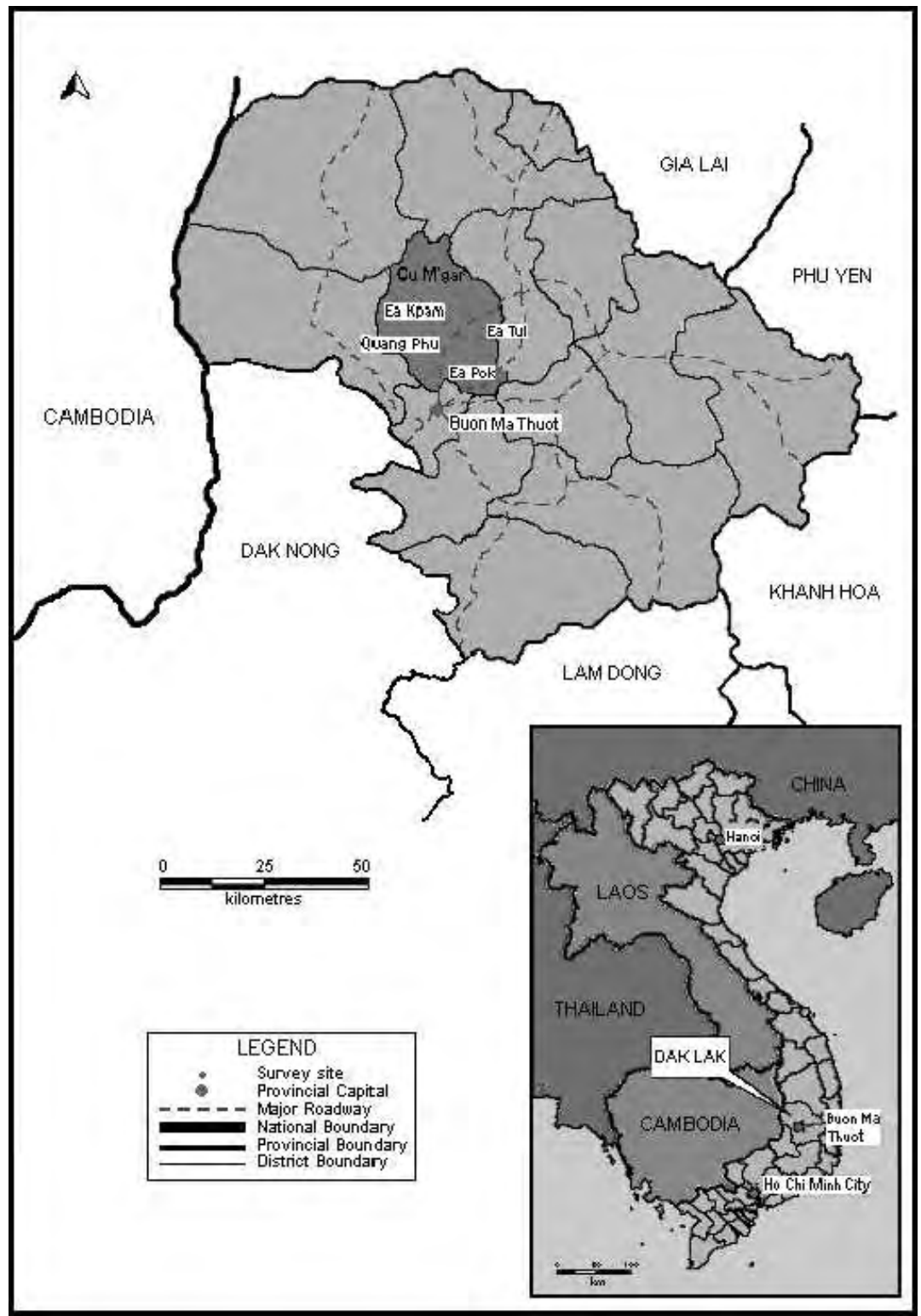

Figure 1. Cu M'gar District of Dak Lak Province, Vietnam Central Highlands Note: The "old" Dak Lak was split into two provinces in early 2004: Dak Lak (shown in the above figure) and Dak Nong. 
Just after World War II Hemileia vastatrix attacked Arabica coffee; from 64.5 percent of southern Vietnam's coffee in 1945, Arabica output decreased to 1.7 percent in 1957 (Teulières 1961:86). One Robusta variety, canephora, proliferated due to its disease resistance and good returns. For a variety of reasons, however, embattled French administrators discouraged farmers from coffee cultivation and recommended that they concentrate on annuals such as rice. Many Kinh farmers left the Highlands and returned to lowland coastal areas to farm.

After the French defeat at Điện Biên Phủ in 1954, what coffee production remained was dominated by large plantations, sometimes with great increases in cultivated areas. ${ }^{3}$ In certain regions of the country, the new government encouraged coffee cultivation through subsidies, tax exemptions, and protectionist measures as well as through research on improved varieties. This pattern persisted up through reunification in 1975, at which time state farms replaced colonial plantations (Fortunel 2000).

In the late 1970s, economic and social reforms generated a labor shortage in the Central Highlands, and the Vietnamese government began actively promoting the migration of ethnic Kinh to the region (Hardy 2003). While poverty and overpopulation plagued some of Vietnam's lowland areas, the less populated highlands seemed to offer unlimited opportunity for expansion and exploitation. Additionally, military control in the highlands was poor, so settlement there improved national security and helped to guard against uprisings by ethnic minorities. The government thus organized large nationwide migration movements, with pledges of cleared fertile land and income from coffee production. Even after official government resettlement ended, the "free flow" inertia of in-migration in pursuit of coffee wealth continued throughout the 1990s. It is likely that between four and five million people migrated to the Central Highlands after 1975. While the population density in the Highlands was around three persons per square kilometer in 1940, by 1997 it had reached seventyseven persons per square kilometer (Fortunel 2000). These changes in population distribution and density were accompanied by ecological pressures, as will be noted below.

In 2002, the population growth rate of Dak Lak Province was, at 6.18 percent per annum, the highest in Vietnam. The province's population was about 1.8 million people (Oxfam 2002: 11). The ethnic transfor-

\footnotetext{
${ }^{3}$ In 1955 the Central Highlands became part of the Republic of Vietnam (South Vietnam) and the new government (under President Ngô Đình Diệm) assumed management of these areas.
} 
mation was remarkable. In 1920, the Province reported virtually no Kinh residents. Two decades later, its population of 80,000 included 4,000 Kinh. During the French and American wars in the 1950s and 1960s there was a steady Kinh influx, and shortly after reunification, the Kinh constituted 61 percent of the population in Dak Lak (Jamieson 1996). Indigenous minorities such as the Ede and the M'nong, who made up forty-eight percent of Dak Lak's population in 1975, today comprise twenty percent (Oxfam 2002). The Kinh comprise about 70 percent, while other ethnic minorities from the Northern Highlands make up the remainder. The government's plan for the period through 2010 is for Dak Lak to accept another 260,000 people from other parts of the country, the early expressions of which have met with repeated protests by minority ethnic groups (AITPN 2002).

Although coffee cultivation originated in colonial times, it was not until after reunification in 1975 that coffee production gained significant traction. In the late $1980 \mathrm{~s}$, as the government began to dismantle the system of state farms and move toward a market-based economy, coffee area and output expanded exponentially. Large changes in population dynamics accompanied this agricultural transformation. Today, less than one quarter of farmers in the Central Highlands are native to the area. The rest are Kinh who entered the area throughout the 1980s and 1990s, either attracted by the wealth associated with coffee production, resettled through government programs, or pushed out of the rice delta by land shortages. This population shift precipitated significant changes in Ede traditions; meanwhile, land rights have become gradually more important, and various land and migration policies have modified traditional relationships with the land. Thus, opportunities associated with Highland coffee production and preferential treatment in settlement and entitlement as components of post reunification recovery, broadly defined, empowered the Kinh in many ways. Kinh migration to the Central Highlands suited colonial and post-colonial designs for regional integration. Over time, this seeded a process of development-induced displacement for the Ede.

\section{Highland Agricultural Transformation}

The socio-cultural landscape of the Central Highlands has changed profoundly in recent years. After 1975, Vietnam's communist government launched a major resettlement campaign in New Economic Zones (NEZ) to better utilize labor, diversify the economy, accelerate collectivization, and ensure the security of the peripheral 
regions. It simultaneously implemented its Fixed Cultivation and Sedentarization Program (FCSP) to motivate ethnic minorities to abandon shifting cultivation and other nomadic behaviors. Collective ownership of land was instituted at the village-level. Traditional tribal lands were declared state property, eligible for redistribution. Villagers were encouraged to participate in cooperatives, state farms and forestry enterprises. ${ }^{4}$ Throughout the Central Highlands, NEZs brought all types of people together, particularly from the Central Coast. Between 1976 and 1980, nearly half a million people were resettled in the NEZs in the three provinces of the Central Highlands, and another 260,000 were resettled between 1981 and 1988 (Müller 2004). By 1985 there were twenty-five NEZs in Dak Lak Province (Fortunel 2000).

Following widespread food shortages in the 1980s, the government adopted a radically new Economic Renovation Policy (known as Doi Moi). The policy was aimed at promoting socioeconomic development and closer integration with the rest of the world, and involved a shift from a centrally planned economy to a market oriented one, and from a centralized, collective agricultural production system to private ownership of land. It allocated cooperative land to farm households, legalized private ownership of productive assets through ownership "certificates", deregulated agricultural marketing and prices, and devalued the exchange rate (Minot 1998). These reforms resulted in better farm-level prices for coffee and stimulated farmers to expand coffee cultivation.

Before 1988, land policies focused on transferring land from traditional forms of tenure to government control. Since 1988, official policy (the new Land Law) has sought to decentralize land rights from the State back to households and individuals, while reducing the role of the community in land tenure and administration (Tinh 2002). With this change, households in the Central Highlands were entitled to use 1000 square meters of land to support the household economy (Tinh 2002). At the same time, many of the state coffee farms began allocating plots to workers, converting them from members of cooperatives to tenants or renters who were responsible for the production of a given parcel of land (Minot 1998). A second Land Law was passed in 1993. While all land remained, technically, under the ownership of the State, the new law permitted individuals to acquire the right to use and

\footnotetext{
${ }^{4}$ This bias against swidden and subsistence agriculture and the pattern of land tenure reform programs are part of a broader project of consolidation of state control over land that has appeared in other countries. See Vandergeest (2003).
} 
occupy land. Specifically, individuals could now buy, sell, inherit, mortgage and lease land use rights. ${ }^{5}$

As coffee boomed in the 1990s and coffee prices rose, migrants rushed to secure land either by squatting or by purchasing rights from the native highlanders. This pressure on land made villagers aware of its market value. As a result, many asserted claims to the lands they had farmed. Households now had greater security of tenure, and farmers were free to make their own commercial decisions. Coffee was widely adopted by the Ede and Kinh alike, and land certificates became an important way to secure the fruits of family labor. Cumulatively, then, the Land Laws have encouraged farmers to use the land in new ways, expand land under cultivation, reduce shifting cultivation and fallowing, and increase agricultural production so as to compete successfully in global markets.

\section{Coffee: Grounds for Inequality and Displacement}

Despite the rising economic tide associated with coffee in Vietnam's post-unification period, a number of social, economic, and cultural convulsions can be traced to the crop. The new structure of land ownership combined with rising prices for Robusta beans attracted new waves of coffee farmers and foreshadowed the 1990's boom and bust. Between 1986 and 1996, coffee-producing areas grew at twenty-one percent annually, while yields grew at almost six percent annually (Minot 1998). Overall coffee production expanded twelve fold in this decade and challenged the production leadership of other countries (Figure 2). The physical, social, and economic landscape of Dak Lak Province was irrevocably altered, as 6,000 hectares of coffee in 1975 grew to become 130,000 hectares in 1997 (Fortunel 2000). In recent years, coffee exports have come to account for six to twelve percent of the total value of Vietnamese exports (Minot 1998).

While the boom of the 1990s provided employment, new capital, and more consumer goods, it brought unanticipated dislocations as wellthe loss of self-sufficiency, the erosion of mutual assistance, increased social stratification, vulnerability to external forces (Dang 2003), and diminished environmental security. Currency devaluation and fluctuating world coffee prices wrought havoc on farmers integrated into the cash economy, particularly if they had abandoned polyculture and committed as much of their land as possible to coffee production.

\footnotetext{
${ }^{5}$ This 1993 Land Law reinstated certain elements of traditional land use, namely, granting of land use rights to farmers. Yet it also strengthened the State's control over land through the recognition of the legal land use rights, granting land use right certificates and imposing land taxes.
} 


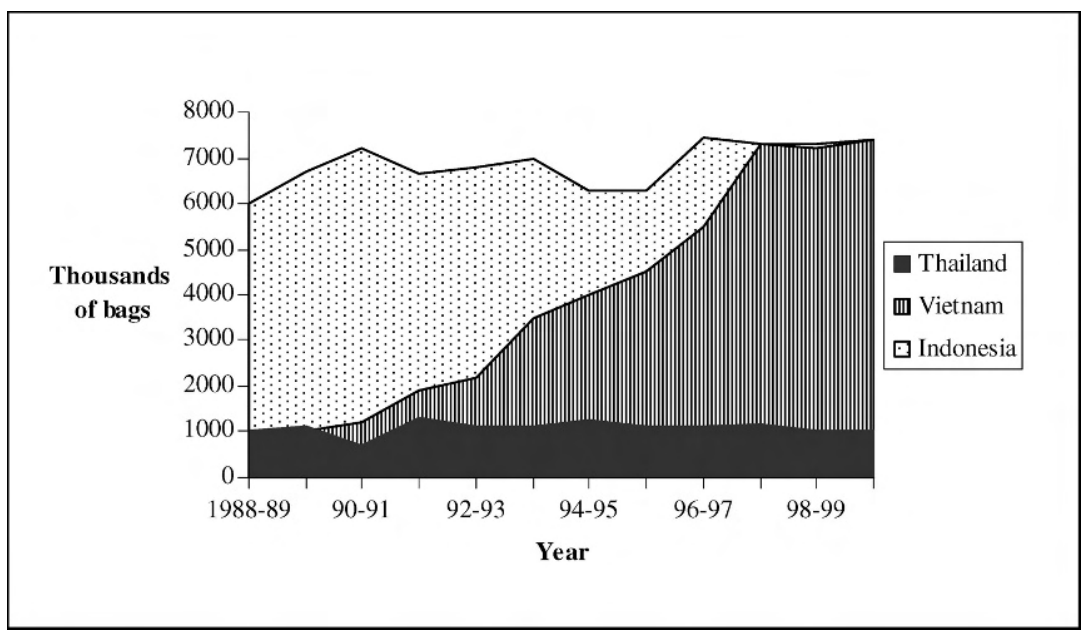

Figure 2. Vietnam Coffee Production within South East Asia

Source: Better Investments Coffee Newsletter, www.binews.com, in Fortunel (2000:8).

When the world price of coffee dropped in 2001, some households were forced to reduce their daily number of meals, and others changed their diet or increased their reliance on food donations from local authorities. Farmers who in 1999 could get \$1.40 per kilo of coffee suddenly earned only forty cents. While educational levels had improved in the 1990s, many children of medium-off or poor households were now forced to quit school. A 2002 Oxfam report concluded that high coffee prices between 1995 and 1999 helped local people to purchase bicycles, television sets, motorbikes, tractors, and water pumps. Declining coffee prices thereafter generated food security problems and reversed consumption patterns. Oxfam (2002) reports that, at the time of their survey, forty-five percent of coffee-growing households lacked adequate nourishment, sixty-six percent had bank debts, and nearly half had replaced self-employment and subsistence with wage labor work.

Meanwhile, environmental conditions in the Central Highlands have been deteriorating. In the past three decades, in addition to deforestation and defoliation, chemical residues and landmines, erosion, and acidification and loss of biodiversity, rapid population growth led to environmental stress (Rambo and Jamieson 2003). ${ }^{6}$ With

\footnotetext{
${ }^{6}$ Between 1943 and 1993 the proportion of the national territory covered by forests declined from at least forty three percent to twenty percent (De Koninck 1999) and since 1996, more than 120,000 hectares of forest have been cleared for new coffee plantations in Dak Lak Province alone (Greenfield 2004).
} 
ancestral forest domains converted into coffee plantations, many ethnic minority people joined the rush to clear forest and plant the "dollar tree." One consequence is that today "deforestation is considered by many Vietnamese to be the most serious environmental problem facing the nation" (Di Gregorio, Rambo and Yanagisawa 2003:174).

In DID terms, there is little doubt that a classical development scenario has unfolded in Vietnam around coffee. Policies put in place first by the colonists, then by the government of the Republic of Vietnam, and finally by the Socialist Republic of Vietnam, focused on territorial improvement, strategic imperatives and population management. ${ }^{7}$ The sharp sectoral advance in agriculture due to coffee permitted an intersectoral transfer of wealth with numerous multipliers and a strong contribution to gross domestic product (GDP). ${ }^{8}$ The accompanying reforms and course adjustments sparked an extraordinary boom in Vietnamese foreign trade: from $\$ 2.5$ million in 1985 to over \$31 million in 2001. Between 1991 and 2001, Vietnam was one of the fastest growing economies of the world, with GDP rising at rates averaging 7.7 percent per annum and per capita GDP growth in that period of 6.1 percent (World Bank 2002a). But per capita depictions obscure the topic of the present study, namely the differences in earning power among different ethnic groups.

\section{The Ede: Effects of the Land Laws}

Are these DID impacts experienced differently by the Kinh and the Ede? The demographics alone are revealing. As noted above, the Kinh represented six percent of the Highland population around 1940 and accounted for seventy percent in 1996 (Fortunel 2000). The implications of this change for displacement are far-reaching. As elaborated by Dang (2003:91): “Traditionally, Ede society was characterized by a high degree of stability and relatively homogenous households. Although there were poor and rich in the village, social differentiation was not drastic. Now, however, there are significant differences in wealth among the households, and the poor make up a large proportion of the population.' Dang observes significant differences in housing, as well as in access to land: while some villagers still have many fields for both coffee and subsistence production, others face a severe shortage of land for the latter purpose.

The 1993 Land Laws' support for "permanent agriculture" also has an important ethnic subtext. Planners intended these laws to raise

\footnotetext{
${ }^{7}$ According to Fortunel (2000:29), there has been an overall long term goal of "civilizing" the Central Highland area, through sedentarization of its "savage" people.

${ }^{8}$ Twenty four percent in 2001 (World Bank 2004: ix).
} 
welfare by preventing "destructive" cultivation systems. By seeking the end of swidden systems in particular, the reforms replaced fallowing with other approaches to soil fertility, most requiring capital, chemical inputs, or additional labor. Ending fallow rotations has social and ecological side effects for cultures that depend on them (Vandergeest 2003). It undermines native agroforestry and the forest-farming associations within the Ede culture, and also removes an important behavioral barrier for forest clearing, the associated bio-depletion, and the "forest fallback" option which has long served the Ede as sustenance security in times of drought, natural calamity, or national crisis. State policy has greatly undermined traditional agricultural practices and the ethnic groups most dependent on them (Dang 2003).

Other observers affirm this view (Plant 1994; Tinh 2002). In some localities, land allotment was unequal between households. Limited land quotas in more mountainous areas widened the asset gap between households and initiated land disputes (in some areas, some households can hold as much as twelve times more land than their neighbors). As planners intended, the Ede turned to cash crops like coffee to supplement their incomes. Beyond changing traditional land tenure from communal to household ownership, the laws also construed extended families living in one longhouse as a single household. "The "Red Books" issued to families as their certificate description often bore the name of the senior man, largely ignoring the matrilineal nature of the Ede and the tradition of wife as house-holder (Dang 2003:85). An arbitrary limit was imposed on the amount of land granted to each longhouse regardless of how many nuclear families it contained. This forced many families to leave the longhouse and establish separate homes as a way to access legal coffee parcels.

In the past, longhouse members often worked the fields and shared food together. A senior female member of the longhouse was responsible for overseeing and managing longhouse affairs. In the "new" economy of privatized land, nucleated families, and coffee speculation, young members networked with outsiders and became key purveyors of technology, farmer know-how, market connections, and access to loans (Dang 2003). Intergenerational rifts were common, for example as these younger entrepreneurs planted coffee outside of collective efforts and then claimed the harvest as their own property. Moreover, the competition for coffee space left little land for rice

\footnotetext{
${ }^{9}$ The Communist Party viewed longhouses as survivals from a primitive stage of culture that had to be destroyed if the Ede were to evolve to a higher evolutionary stage. In some areas, Party cadre deliberately burned longhouses (Rambo 1995).
} 
cultivation or for hunting and gathering. Increasingly, villagers came to rely on food purchased rather than grown.

So to say that $E d e$ village economies changed from subsistence to cash crop production only begins the inventory of in-situ losses besetting their households. The same Land Laws had far less impact on Kinh inmigrants. In most areas of the country, official land-use rights and household land ownership had long been the norm, formally or informally. Among the Kinh, kinship is patrilineal, and men are the owners and allocators of land. Moreover, the migrants generally arrived in the area with nuclear families and related customs, including similar land allocation and use decisions. The Land Law reforms reinforced most farming and community practices among the Kinh, such as they were. If recent protests are an indication (AITPN 2002), coffee-based DID is in most ways specific to the Ede.

\section{Development-Induced Displacement}

DID inscribes new terminology on a phenomenon of long-standing interest in sociology (Vandergeest et al. 2007). Recent DID reincarnations are found in the literatures on boomtowns (see Freudenburg 1992), urban renewal (Cernea 1989; Thompson 2004), on infrastructural developments (Thukral 1992), and, on more generalized cases as suggested in typologies advanced by the Brookings Institution (Cohen and Deng 1998). Vandergeest and colleagues (2007) have assisted DID researchers by shifting their gaze to cases of rural land policies that enhance the life chances of some populations at the expense of others. On few occasions, however, has DID been conceptualized as occurring in-situ - that is, without spatial movement, expulsion, or flight.

Coffee related developments in central Vietnam have attracted the attention of economists (Glewwe, Gragnoalati, and Zaman 2000; Ha and Shively 2008; Van de Walle and Gunewardena 2001) and others attentive to questions of social change in the Central Highlands (Baulch et al. 2002; Dang 2003). Baulch and colleagues (2002) have examined the disparities in living standards between and among the different ethnic groups in Vietnam. They show that, amid the growth in the 1990s, the Kinh households attained substantially higher living standards than minority households, and that the income position of the Central Highland minorities stagnated. Some ethnic minorities seem to have prospered due to assimilation (both economic and cultural) with the Kinh majority. Others are attempting to integrate economically while retaining distinct cultural identities; and a third group is largely being left behind-or displaced-by the growth process. 
Several authors have examined the sources of inequality. Joint work by Action Aid Vietnam and the Centre for Rural Progress (CRP) (2000) reports the impacts of recent agricultural change on households in the Central Highlands. It reveals that changes vary across different income groups depending on their initial endowments and educational attainment. According to the report, the inhabitants of Dak Lak Province have not been equally successful in capturing their income-generating opportunities due to different resources, mainly capital and land. Households having higher educational attainment and younger heads are likely to have benefited more from the boom in the coffee sector.

Furthermore, the authors note that risks to coffee-dependent households are significant, especially price risk and natural calamities. For the poor and near-poor, the adverse impact of large price fluctuations is severe. Van de Walle and Gunewardena (2001) argue that disparities in levels of living between the minority and majority ethnic groups are not just matters of geography; they vary within regions as well. In general, minority households have lower levels of education, a larger size, fewer children in school, and fewer non-farm economic opportunities. Minority households often achieve higher returns to their land, something the authors attribute to working harder on their land due to a lack of other opportunities. Their study shows that, country-wide, geographic location matters much more to the ethnic minorities' living standards than to those of the majority.

In an article on the economic and social impact of commodity production on a Central Highlands community, Dang (2003) observes that cash cropping is an uncertain way to improve livelihood of minority groups. Whereas cash crops can achieve a higher money return, they can also bring unanticipated costs to the communities stemming from market fluctuations, loss of self-sufficiency, erosion of mutual assistance ethics, and social stratification-that is, inequality between ethnic groups. Ha and Shively (2008) examine coffee farmers' responses to falling producer prices for coffee and find that Kinh migrants are more likely to change crops, borrow, or look for off-farm employment than members of ethnic minority communities. They argue that the lack of responsiveness on the part of minority farmers reflects low agricultural capacity, lack of opportunity and exclusion from economic networks dominated by the Kinh.

The general paucity of data on coffee-related welfare is something of a deterrent to innovative DID thinking. Nonetheless, the above studies consistently show that ethnic majorities tend to be better off than minorities. From one standpoint, this result could be seen in an egalitarian society as an achievement, assuming that assimilation policies are taking hold and that both groups are gaining relative to 
the previous situation or a reasonable counterfactual scenario (i.e., the development trajectory that would have evolved in the absence of coffee). From another perspective it may suggest deprivation for an enduring minority whose losses are underestimated or ignored simply because they have not been physically displaced.

\section{Study Design and Methodology}

We now turn our inquiry to a closer analysis of the relative condition of ethnic minority coffee growers and document their recent experience. We use 2003 data gathered from 209 farmers in four coffee-growing communities of $\mathrm{Cu}$ M'gar district, ${ }^{10}$ in the heart of Dak Lak Province. We periodically enrich these interviews with findings from a 1999 Dak Lak agro-socio-economic survey ${ }^{11}$ and first-hand observations by two of the authors at different times during 2004 and 2005. The 2003 data were collected by researchers at Nong Lam University using paper questionnaires and trained enumerators. The survey was part of a follow-up to a 1999 study of Central Highland coffee growers, summarized in Ha (2000). The sample was stratified across villages in order to capture major environmental and socio-economic features of the landscape, especially with regard to production techniques and water use (which has emerged as a major concern in many coffee growing areas). Within chosen villages, sample farmers were selected at random from the village population of coffee farmers. Although the data are indicative of the situation in the Central Highlands, the survey data should not be construed as fully representative of all coffeegrowing districts; one must note that there are important differences between different parts of the Central Highlands and also among the different ethnic groups. Approximately two-thirds of the observations $(\mathrm{n}=144)$ come from Kinh households and one-third $(\mathrm{n}=65)$ come from Ede households, sampling percentages roughly consistent with the underlying population shares of Kinh and Ede and other ethnic

\footnotetext{
${ }^{10} \mathrm{Cu}$ M'gar is primarily a coffee producing district, one of the biggest in the Dak Lak Province. It is located thirty kilometers north of Buôn Ma Thuột, the provincial capital, and it consists of 13 communes and two towns. The population is about 139,000 living on an area of 825 square kilometres. The majority of coffee producers in the district are individual farmers; in addition, there is a small number of large state farms or coffee companies.

${ }^{11}$ In 1999, an agro socio economic survey was carried out in the Cu M'gar district. The goal was to collect agricultural input and output data to determine local crop production systems in the context of a feasibility study for construction of the Buon Yong dam. The survey was carried out by local project staff project, as well as province, district and commune officials, in collaboration with a team from Nong Lam University in Hô Chí Minh City.
} 
minorities in the Central Highlands. Below, we focus specific attention on household incomes in order to compare Kinh and Ede returns from coffee. As will be shown, bivariate and multivariate analyses lead to different conclusions, especially when we control for the effects of several variables noted in the above studies-education, various labor arrangements, farm size, use of incentives to grow coffee, and ethnicity—and various interaction effects.

\section{Dak Lak Province}

Dak Lak Province is the heart of Vietnam's coffee-growing area. Located in the Highlands of Western Vietnam, the province covers 13,062 square kilometers, including about 264,000 hectares that were under coffee cultivation in 2000 (Greenfield 2004). In 2003, the province held over fifty percent of the area dedicated to coffee in the country and was responsible for sixty percent of coffee production. ${ }^{12}$ Important to our analysis, coffee earnings accounted for ninety-five percent of local income. Dak Lak experienced high rates of in-migration between 1976 and 1998, with the absorption of well over half a million new settlers, and a quadrupling of the baseline population (Xuan 1998).

Dak Lak's tropical climate is favorable to the growth of many crops, including rubber, black pepper, fruit trees, cocoa, hybrid maize, beans and cotton. Yet its thick basalt soil and two growing seasons are particularly favorable to Robusta coffee. The dry season lasts four to five months and permits harvesting and drying without excessive fuel consumption. Groundwater supplies are replenished by June monsoons; average annual rainfall is about 1700 millimetres (Oxfam 2002). The 500 to 700 meter altitude in the Central Highlands accounts for high temperature differentials between night and day, ideal for coffee production (Nhan 2001).

\section{Household Income Comparison}

Agricultural production provides the largest proportion of income for Highland farming families, and the main source of income for most farmers is coffee production. Our analyses of Ede and Kinh household incomes ${ }^{13}$ offer an optic for examining the ethnic dimensions of this production.

\footnotetext{
${ }^{12}$ Vietnam news, http://vn style.com/viewDetails.asp?sca 17\&PostID 14202.

13 "Income" refers to cash income only. The survey does not take into account in kind income. Since the Ede tend to be more reliant than the Kinh on collection of wild products and garden products for their own consumption, their income may be higher if the value of these products was included.
} 
Table 1. Characteristics of Coffee Farms, Dak Lak Province, 2003

\begin{tabular}{lccc}
\hline & Kinh Farms & Ede Farms & All Farms \\
\hline Household size (number) & $5.3^{*}(1.61)$ & $7.1^{*}(2.07)$ & $5.9(1.95)$ \\
Age of household head (years) & $45.4(11.66)$ & $44.7(11.21)$ & $45.2(111.53)$ \\
Education of household head & & & \\
$\quad$ (years) & $8.0^{*}(2.98)$ & $4.8^{*}(4.15)$ & $6.98(3.68)$ \\
Farm size (ha) & $1.38^{*}(0.95)$ & $1.97^{*}(1.03)$ & $1.56(1.01)$ \\
Area planted to coffee (ha) & $1.09^{*}(0.76)$ & $1.74^{*}(0.95)$ & $1.29(0.87)$ \\
Age of coffee trees (yrs) & $11.4(4.61)$ & $12.0(5.62)$ & $11.6(4.89)$ \\
Coffee yield (kg/ha) & $3045^{*}(1272)$ & $2044^{*}(1847)$ & $2734(1244)$ \\
Income (1,000 D) & $50,084^{*}(35,479)$ & $37,228^{*}(25,183)$ & $46,086(33,108)$ \\
Income per capita (1,000 D) & $10,015^{*}(7961)$ & $5,735^{*}(3968)$ & $8,684(7237)$ \\
Off farm income (1,000 D) & $4510(10,297)$ & $3994(7,759)$ & $4351(9,572)$ \\
Share of income from coffee & $0.76(0.43)$ & $0.86(0.35)$ & $0.79(0.41)$ \\
Family labor (days) & $153.2^{*}(81.4)$ & $184.8^{*}(81.2)$ & $163.0(82.5)$ \\
Hired labor (days) & $71.5^{*}(73.5)$ & $36.6^{*}(53.0)$ & $60.7(69.6)$ \\
Incentives (1 used incentives; & & & \\
$\quad 0 \quad$ didn't) & $0.47^{*}(0.50)$ & $0.75^{*}(0.43)$ & $0.55(0.49)$ \\
Tenure (\% of farm area with title) & $0.84^{*}(0.32)$ & $0.67^{*}(0.35)$ & $0.78(0.34)$ \\
Number of observations & 144 & 65 & 209 \\
\hline
\end{tabular}

Note: standard deviations in parentheses. ${ }^{*}$ indicates means are significantly different in paired t test at $10 \%$ test level. In 2004, $\$ 1 \mathrm{US} \approx 15,787 \mathrm{D}$.

Source: Computed by the authors using 2003 survey data. See Ha and Shively (2008).

Our 2003 survey data are summarized in Table 1. Basic patterns in the data indicate that Ede households were significantly larger (7.1 members vs. 5.3 members) and less well educated (4.8 years vs. 8.0 years) than their Kinh counterparts. Ede occupied significantly larger farms (1.97 ha vs. $1.38 \mathrm{ha}$ ), and planted a significantly larger share of that land with coffee $(88 \%$ vs. $79 \%)$. Although the age of coffee trees did not differ between the two groups, Ede achieved considerably lower coffee yields (2044 kg/ha vs. $3045 \mathrm{~kg} / \mathrm{ha}$ ) and, as a result, incomes that were approximately seventy-five percent of those of Kinh households (and nearly half of the Kinh level when measured on a per-capita basis). Overall, both Ede and Kinh households in the sample appear to have been highly reliant on coffee, although coffee's share in total household income was somewhat higher (0.86) for Ede households. Kinh households had significantly higher rates of formal tenure than did Ede respondents.

Turning to the pair-wise correlation between household income and ethnicity $(r=0.19)$, we find that it is negative and statistically significant (Table 2). Family incomes for the Ede are generally lower than for the Kinh. The Ede exhibit lower levels of general education among household heads ( 0.40$)$ but make more use of incentives to grow coffee $(0.27)$, perhaps as a result of targeted extension efforts in the province. In contrast with the speculation above, family income is 
Table 2. Pearson Correlations of Household Income, Ethnicity, and other Production-Related Variables in Cu M'gar District, 2003

\begin{tabular}{lccrrrr}
\hline & Income & Ethnicity & Education & $\begin{array}{c}\text { Family } \\
\text { labor }\end{array}$ & $\begin{array}{r}\text { Hired } \\
\text { labor }\end{array}$ & $\begin{array}{c}\text { Use of } \\
\text { incentives }\end{array}$ \\
\hline Income & 1.00 & $-0.19^{*}$ & $0.13^{*}$ & $-0.28^{*}$ & $0.35^{*}$ & -0.07 \\
Ethnicity & & 1.00 & $-0.40^{*}$ & $0.18^{*}$ & $-0.23^{*}$ & $0.27^{*}$ \\
Education & & & 1.00 & $-.25^{*}$ & $0.28^{*}$ & $-0.16^{*}$ \\
Family labor & & & 1.00 & $-0.64^{*}$ & $0.18^{*}$ \\
Hired labor & & & & 1.00 & -0.07 \\
Use of incentives & & & & & 1.00 \\
\hline
\end{tabular}

$\mathrm{N}$ 209. * indicates pair wise correlation is significant at $95 \%$ confidence level (1 tailed test).

Source: Computed by the authors using 2003 survey data. See Ha and Shively (2008).

negatively correlated with the use of household labor $(0.28)$ and is positively correlated with hired labor (0.35). Compared with the Ede, the Kinh tend to rely more on hired labor and less on family labor. It may be that Ede family labor is occupied with non-income generating activities, although this conjecture cannot be tested with available data.

Given the correlations between ethnicity and use of incentives, education, and labor, we might expect to find an income differential favoring Kinh over Ede. ${ }^{14}$ Indeed, in our first regression model (see Table 3, column 1), we find that Ede ethnicity is negatively correlated with income, after controlling for other factors. ${ }^{15}$ Although the results suggest joint significance of the regressors, the overall explanatory power of the regression is weak (adjusted $\mathrm{R}^{2}=0.14$ ), and most individual point estimates of the regression coefficients are statistically weak. The exception is hired labor. Nevertheless, our perspective is that labor hiring is as much a result of high household income as a cause of that income. It is important to note that farm size has a strong pair-wise correlation with household income $(r=0.574)$ and also varies with ethnicity. ${ }^{16}$ It also links our analysis to the Land Laws. Ede households generally have larger farms. On average, their farms are 1.9 hectares, while Kinh farms are 1.3 hectares. When the sample is divided between large and small farms (over and below the overall mean of 1.5 hectares), we find that the Kinh have more small farms and the Ede

\footnotetext{
${ }^{14}$ Here we use data from all four communities. The four communities are Ea Tul, Quang Phu, Ea Pok, and Ea Kpam, all located in the Cu M'gar district of Dak Lak Province. Quang Phu, Ea Pok and Ea Kpam have a majority of Kinh farmers, while Ea Tul consists of a majority of Ede farmers.

${ }^{15}$ In 1999, the Kinh were significantly more educated than the Ede. Average schooling in Ea Tul was four years, compared to about eight in Quang Phu (Ha 2000).

${ }^{16}$ Farm size refers to the total landholdings, including both cultivated area and fallow land.
} 
Table 3. Household Income Regression (income in 1000 Dong)

\begin{tabular}{lrrr}
\hline & \multicolumn{1}{c}{ Model 1 } & \multicolumn{1}{c}{ Model 2 } & \multicolumn{1}{c}{ Model 3 } \\
\hline Constant & $4,378(4.58)$ & $14,021(1.78)$ & $8,420.2(1.08)$ \\
Ethnicity (0 Kinh, 1 Ede) & $-7,795.4(1.48)$ & $-23,301.2(5.40)$ & $-1,594.5(0.22)$ \\
Education (years of head) & $-67.3(0.10)$ & $-24.4(0.05)$ & $53.9(0.11)$ \\
Family Labor (person days/ & $-34.9(1.01)$ & $6.1(0.23)$ & $0.1(0.0)$ \\
$\quad$ year) & & & \\
Hired Labor (person days/year) & $126.9(3.07)$ & $70.9(2.18)$ & $64.2(2.03)$ \\
Used incentives (1 yes; 0 no) & $-630.8(0.14)$ & $-2,711.5(0.76)$ & $-2,294.6(0.66)$ \\
Farm size (hectares) & & $21,416.1(11.5)$ & $26,135.9(11.7)$ \\
Ethnicity $\times$ Farm size & 0.14 & 0.48 & $-12,761.8(3.59)$ \\
$\mathrm{R}^{2}$ & 209 & 209 & 0.51 \\
Number of observations & & & 209 \\
\hline
\end{tabular}

Note: absolute value of t statistic appears in parentheses.

Source: Computed by the authors using 2003 survey data. See Ha and Shively (2008).

more large farms (Figure 3). We thus return to regression analysis with a new question in mind: does farm size function differently in the two cultural contexts?

To address this question we present results from a second income regression in the second column of Table 3. Model 2 adds farm size to the list of regressors from Model 1. As in Model 1, the coefficients in Model 2 are jointly significant at standard test levels. Importantly, the adjusted $\mathrm{R}^{2}$ more than triples from the level in Model 1 to 0.48 , indicating that farm size adds important explanatory power to the regression. Nearly half of the total variation in household income is explained by this regression. Controlling for farm size strengthens the explanatory power of ethnicity. Once again, ethnicity is negatively related to income, despite the fact that, on average the Ede have larger farms. Taking farm size into account, Kinh families are much more likely to have a higher income than are Ede families.

The pattern exhibited in Model 2 affirms income inequality based on ethnicity, but the question remains, why? On its face, the pattern seems counterintuitive. Large farm size should avail a clear advantage to the Ede based on the high correlation between farm size and family income. Results in the final column of Table 3 provide some insights into the connections among ethnicity, farm size, and income. Regression Model 3 incorporates an interaction between ethnicity and farm size. The importance of farm size increases beyond that of Model 2. Furthermore, the interaction term between ethnicity and farm size is statistically strong and replaces ethnicity as the next most important explanatory variable in the regression. Farm size does seem to influence family income in different ways for the two ethnic groups. It is less important for the Ede who enjoy larger farms and more important for 


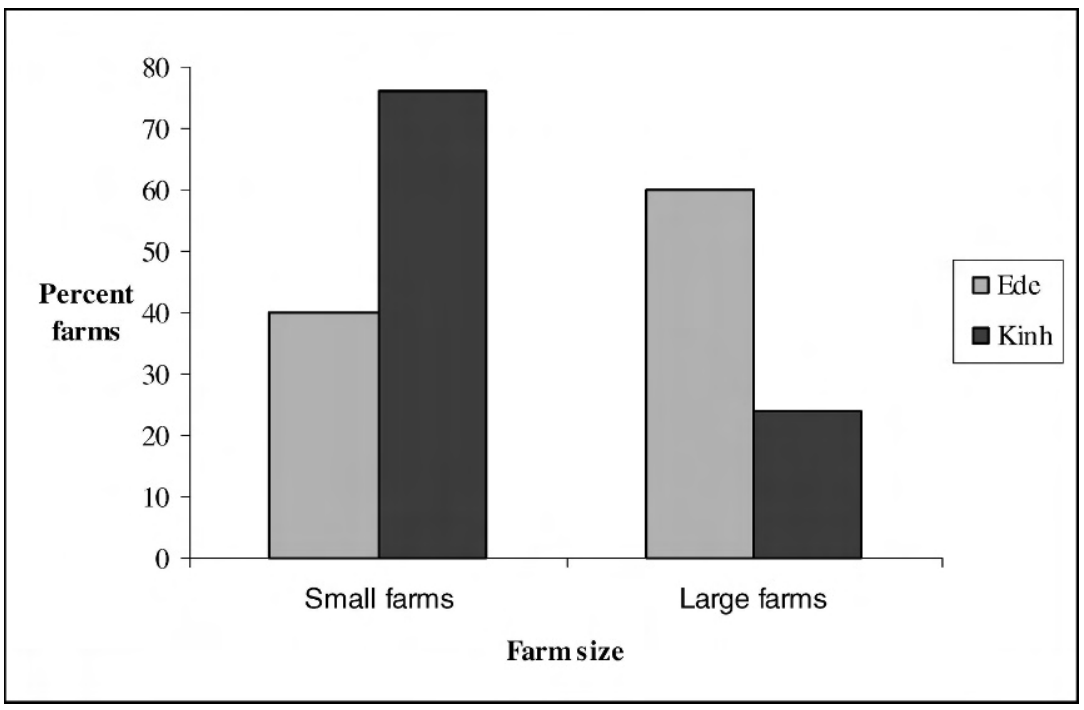

Figure 3. Farm Size According to Ethnic Group

Note: Here, small farms are defined as $\leq 1.5$ ha and large farms are $>1.5$ ha.

Source: Computed by the authors using 2003 survey data. See Ha and Shively (2008).

the Kinh who have smaller farms. Both farm size itself and the use to which the land within farms is put are heavily influenced, as noted above, by government land policies.

These findings suggest the coffee boom in Vietnam's Central Highlands provides a classic example of economic development with displacing side effects. These side effects express themselves in terms of differential income benefits between the ethnic minority that has long inhabited the Highlands and the ethnic majority that-with state encouragement-has migrated to the region in recent decades. In addition to the generally unforeseen consequences of the boom noted earlier and their ethnic dimensions, our analysis suggests that household incomes among the Ede do not match that of the Kinh, despite the larger farm size of the former. This finding, that the Ede are endowed with more land but not higher family incomes becomes interpretable when seen through the lens of in situ displacement, to which we now turn.

\section{In-Situ Displacement}

The income discrepancy which holds our attention here could be explained in a number of ways. Work ethic could account for the higher per family income levels from coffee enjoyed by the Kinh. Despite a 
smaller average farm size, they have consistently obtained higher yields of coffee per hectare than the Ede: roughly triple in 1999 (Ha 2000), double in 2002 and close to fifty percent higher in 2003 (Doutriaux 2005). Differences in household dependency ratios may also explain variations in family income. The $E d e$ have considerably larger families (7.1 members) than the Kinh (5.3 members) - thus probably a higher dependency ratio, which would tend to lower productivity. Furthermore, the Kinh may hire labor because their family is small and thus short on labor to manage production; contracted labor would bring better skills and work commitments. Family labor, in contrast, could be unpaid work (probably women and children in the longhouse tradition) with less education, technical know-how and productive skills, and less contact with extension officers. The Kinh may also be advantaged by their familiarity with coffee cultivation, their higher levels of education, and the irrigation services and chemical inputs their higher incomes permit them to purchase (Ha and Shively 2008). Or perhaps the Ede naively sold their better lands to the Kinh and retreated to less fertile areas. Unlike the Kinh, the Ede lack sustained experience with commercial crops, market networks, and credit sources. Their conversion to sedentary agriculture has largely occurred in the past quarter century.

These explanations are plausible but partial. They fail to tell us why farm size serves fundamentally different purposes in the survival strategies of the two groups. We conjecture that farms held by the Ede are multi-functional in a broad sense and serve as a cultural safety net unlike anything experienced by the Kinh in their relationship with their land. It is a safety net that the Land Laws are intended to discourage or extirpate (displace "in place"), but which persists for a mixture of cultural reasons. Powerful community expectations continue to operate among the Ede and emphasize collective survival. Fallowing, polyculture, crop rotations, and forest protection for diverse reasons all require space and deter individual Ede families from committing their farms to exclusive production.

Recall that until unification in 1975 , Ede society retained many of its customary practices. Bui Minh Dao (2000) reports that most of the forest and land in the Highlands was still subject to traditional management and communal land tenure. During this period, Vietnamese coffee production was not yet extensive, nor was there much interaction between ethnic groups in the Highlands. Starting in 1976 , with the gradual and then dramatic spread of coffee cultivation, Kinh in-migration, and quasi-privatization policy, these patterns changed. Through its Fixed Cultivation and Sedentarization Program 


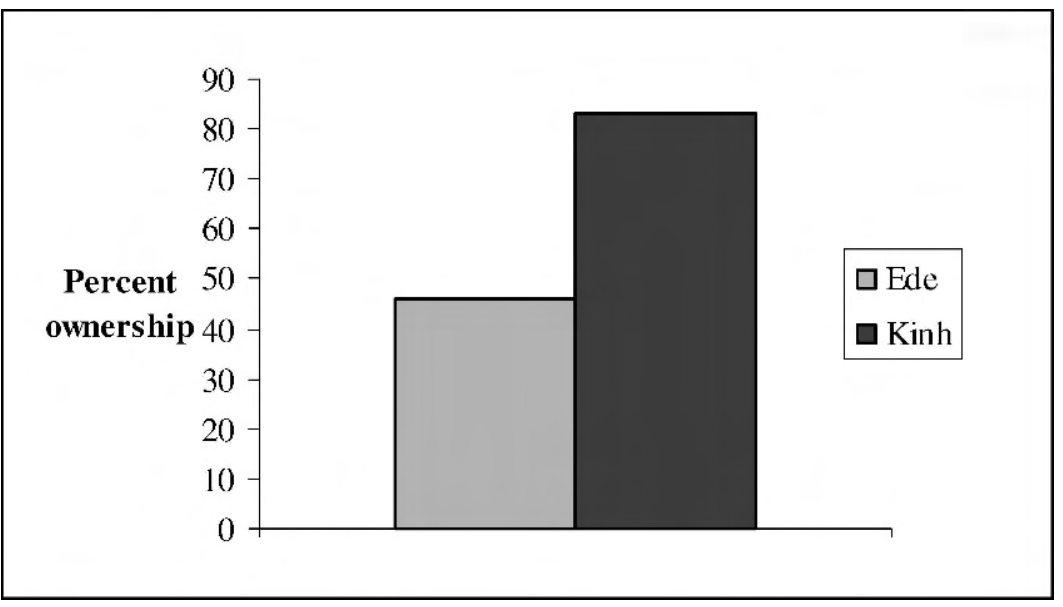

Figure 4. Land Ownership by Ethnic Group, 2003

Source: Computed by the authors using 2003 survey data. See Ha and Shively (2008).

and Land Laws, the Vietnam government set about assimilating the Highland people who stood apart in terms of language, culture, property institutions, and identity (Dang 2003; Dournes 1974; Van de Walle and Gunewardena 2001). Certificates were issued but did not extend to holdings used for traditional, communal ends. The result was that some Ede retained large farms but had certificates only for smaller parcels within that dedicated to cash-cropping.

Figure 4 displays the proportions of Ede and Kinh households in our study that reported holding 100 percent of their land through official Land Use Certificates. By 2003, only forty-six percent of Ede households in our study held Land Use Certificates for their entire farm. The equivalent figure for the Kinh was eighty-three percent. The contrast becomes even more accentuated when each ethnic group is divided by large and small farm size, as they are in Figure 5. Now, instead of fortysix percent, only twenty-three percent of Ede farmers fully owned their large farms, indicating that farm size corresponds poorly to coffee cultivation for the Ede but corresponds rather well for the Kinh. For the latter, the overwhelming pattern is small farms, nearly two-thirds of them fully owned. In other words, large farms are somewhat irrelevant as a predictor of coffee cultivation and related income for the Ede. They officially own only a fraction of their farms, which, like Kinh farms, are heavily planted in coffee. ${ }^{17}$

\footnotetext{
${ }^{17}$ The proportion of farmland (whether owned or not) cultivated in coffee is actually slightly higher for the Ede than for the Kinh (88.3 and 78.9 percent respectively).
} 


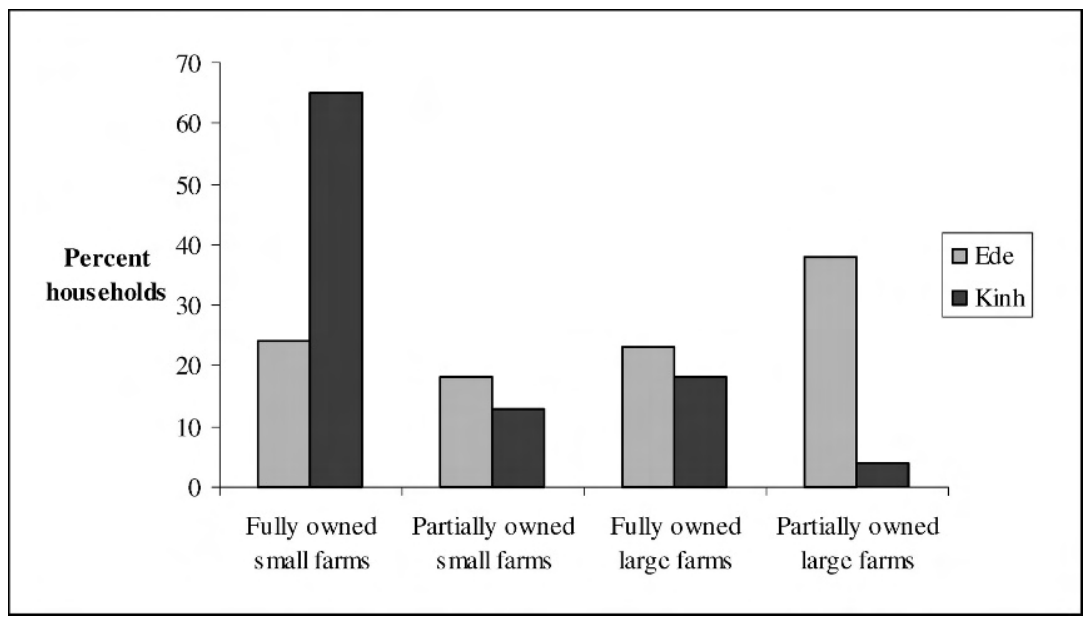

Figure 5. Full and Partial Ownership among Ede and Kinh Households. Small and Large Parcels, 2003

Source: Computed by the authors using 2003 survey data. See Ha and Shively (2008).

We believe the lesson here is this: Ede farmers cannot realize the potential of their larger farm size for lack of certificates to these production units. Secure ownership might encourage productive investments on their land. However, it is not clear that they would change their behavior if they had these certificates. The Ede allocate their labor under cultural expectations, which are long-lived and deeply embedded. The expectation remains that they will manage their landed patrimony for the collective good, that is, for food security, soil fertility, environmental resilience, and community continuity. Like their Kinh counterparts, the Ede use land to hedge against the ups and downs of commercial monocultures and the foibles of regime changes. What differentiates the groups is that, first, for the Ede land serves an important cultural role, and second, the Kinh appear to have preferential access to inputs that make their land more productive, and privileged access to opportunities (such as the labor market) that offset risks. The government increasingly uses land as a commodity to compete in a global marketplace. By not recognizing land that fails to conform to national production plans, the government is shrinking the Ede traditional land base. It is displacing the Ede without forcing them to physically move. ${ }^{18}$

\footnotetext{
${ }^{18}$ Vietnam's ethnic minorities tend to have higher poverty rates than the majority Kinh majority (Van de Walle and Gunewardena 2001).
} 


\section{Conclusion}

This paper reports on the unequal distribution of benefits from a historic moment in Vietnam's rural economy through the lens of in-situ displacement. Coffee production began in Indochina on terms that bear little resemblance to those in place today-extensive plantings of Arabica coffee in an estate-based system run by colonials with mercantilist notions of development. Both colonial and communist administrators used the industry of Kinh farmers, an ethnic group capable of shifting between place, commercial crop, and political allegiance in order to survive. It is widely assumed that the coffee boom of the past thirty years has resulted from their sacrifices, adaptability, and government good will. This recent boom in the coffee economy has led to development-induced displacement falling largely on other ethnic groups with minority status-such as, in the case of this study, the $E d e$. Our research translates the ethnic inequalities accompanying the coffee boom into in-situ displacement measured in terms of relative disadvantage and security loss rather than in terms of space, motion, or exile.

The current situation for Vietnamese coffee shows prices inching back up on the world market even as the country is reducing production costs, improving coffee quality, introducing specialty coffees (e.g. organic and gourmet), enlarging overseas and domestic markets, and facing questions of sustainability. ${ }^{19}$ The Vietnam Develop ment Report 2003 indicates expected growth rates in the Vietnam economy over the next few years in the range of around seven percent (World Bank 2002b). This will place Vietnam's economy among the fastest growing of East Asia, after its northern neighbor, China. Over the past decade, Vietnam's economy has doubled in size and poverty has been reduced by half. ${ }^{20}$ These changes bring the country to rank among the best in terms of poverty reduction. The question remains, however, whether Vietnam can reduce poverty and promote ethnic equality.

Vietnam's migration and assimilation policies of the past three decades have shown mixed results in terms of equalizing wealth and welfare. The competition for "coffee space" between the native and non-native ethnic groups in the Central Highlands could be managed differently to reduce rather than reinforce ethnic inequalities and DID. Given current policies, it is likely that the gap, both between and within

\footnotetext{
${ }^{19}$ Doan Trieu Nhan, Chairman of the Vietnam Coffee Cocoa Association, personal communication.

${ }^{20}$ From seventy to about thirty five percent of the population (World Bank 2002c).
} 
ethnic groups, will continue to increase. Some farmers, especially those who are most adaptable and enterprising, will reap high benefits from coffee and other cash crops, while others will be left behind, in part due to attributes ascribed to them. An improved scenario would include policies to improve opportunities for minority groups in terms of education, economic advancement, land ownership, and access to resources.

\section{References}

Action Aid Vietnam and the Centre for Rural Progress. 2000. Globalization and its Impact on Poverty: Case Studies Vol. 3: A Case Study of Rural Households in Dak Lak Province of Central Highlands. Hanoi: Action Aid and the Centre for Rural Progress.

Asian Indigenous and Tribal Peoples Network (AITPN). 2002. "Persecution of Indigenous Hill Peoples of Vietnam. Briefing Paper." In Indigenous Issues 01. New Delhi: AITPN.

Baulch, R., T.K.C. Truong, D. Haughton, and J. Haughton. 2002. "Ethnic Minority Development in Vietnam: A Socioeconomic Perspective." Policy Research Working Paper 2836. The World Bank.

Brocheux, P. and D. Hémery. 2001. Indochine: la Colonisation Ambiguë, 1858 1954. Paris: Découverte.

Burawoy, M., J. Blum, S. George, Z. Gille, T. Gowan, L. Haney, M. Klawiter, S. Lopez, S. Riain, and M. Thayer, eds. 2000. Global Ethnography: Forces, Connections and Imaginations in a Postmodern World. Berkeley, CA: University of California Press.

Cernea, M. 1989. "Metropolitan Development and Compulsory Population Relocation: Policy Issues and Project Experiences." Social Development Dialogue, 1224.

Cernea, M. and C. McDowell. 2000. Risks and Reconstruction: Experiences of Resettlers and Refugees. Washington, DC: The World Bank.

Cohen, R. and F.M. Deng. 1998. Masses in Flight: The Global Crisis of Internal Displacement. Washington, DC: Brookings Institution Press.

Dang, D.T. 2003. "Coffee Production, Social Stratification and Poverty in a Vietnamese Central Highland Community." Pp. 71100 in Understanding Poverty in Vietnam and the Philippines: Concepts and Context, edited by R. DeKonick, J. Lamarre, and B. Gendron. Localized Poverty Reduction in Vietnam (LPRV) Project.

Dao, B.M. 2000. Land Ownership and Use in the Central Highlands. Hanoi: Social Sciences Publishing House.

De Koninck, R. 1996. "The Peasantry as the Territorial Spearhead of the State in Southeast Asia." Sojourn 11:231 58.

1999. Deforestation in Vietnam. International Development Research Centre. Ottawa, Canada.

Digregorio, M., T. Rambo, and M. Yanagisawa. 2003. "Clean, Green, and Beautiful: Environment and Development under the Renovation Economy." Pp. 171199 in Postwar Vietnam: Dynamics of a Transforming Society, edited by H.V. Luong. Singapore: Institute of Southeast Asian Studies.

Domaine Colonial Français, Le. 1929. Suivi d'un Aperçu Général sur les Colonies Étrangères, Préface de Monsieur le Maréchal Liautey, 1929 30. Paris: Les Éditions du Cygne.

Dournes, J. 1980. Les Autochtones du Vietnam Central. Minority Rights Group. Cited in F. Fortunel (2000:30) Le Café au Viêtnam: de la Colonisation à l'Essor d'un Grand Producteur Mondial. Paris: L'Harmattan.

. 1974. The Montagnards of South Vietnam: Report No. 18. London: Minority Rights Group.

Doutriaux, S. 2005. "Socio Economic Impact of the Vietnamese Coffee Boom on Farmers of Different Background." Master's Thesis. Cornell University, Ithaca, NY. 
Feldman, S., C. Geisler, and L. Silberling. 2003. "Moving Targets: Displacement, Impoverishment, and Development." International Social Science Journal 175:7 13.

Fortunel, F. 2000. Le Café au Viêtnam: de la Colonisation à l'Essor d'un Grand Producteur Mondial. Paris: L'Harmattan.

Freudenburg, W.R. 1992. "Addictive Economies: Extractive Industries and Vulnerable Localities in a Changing World." Rural Sociology 57:305 32.

Glewwe, P., M. Gragnolati, and H. Zaman. 2000. Who Gained From Vietnam's Boom in the 1990's? An Analysis of Poverty and Inequality Trends. Policy Research Working Paper 2275. Washington, DC: The World Bank.

Greenfield, G. 2004. "Vietnam and the World Coffee Crisis: Local Coffee Riots in a Global Con text." in Focus on the Global South. Retrieved January 30, 2007 (www.greenbeanery.ca/bean/ catalog/info pages.php?pages id 56?osCsid eb1424fac50e0c24ec37a429e466c259).

Ha, D.T. 2000. Ea Tul Catchment Agro Socio Economic Survey 1999: Final Report for Support to Water Resources Management in Dak Lak Project. Ho Chi Minh City, Vietnam: Department of Economics, University of Agriculture and Foresty.

Ha, D.T. and G.E. Shively. 2008. "Coffee Boom, Coffee Bust and Smallholder Response in Vietnam's Central Highlands." Review of Development Economics 12(2):312 326.

Hardy, A. 2003. Red Hills: Migrants and the State in the Highlands of Vietnam. Honolulu: University of Hawaii Press.

Henin, B. 2002. "Agrarian Change in Vietnam's Northern Upland Region." Journal of Contemporary Asia 32:3 27.

Hickey, G. 1982. Free in the Forest: Ethnohistory of the Vietnamese Central Highlands, 19541976. New Haven, CT: Yale University Press.

Jamieson, N. 1996. Ethnic Minorities in Vietnam: A Country Profile. Mimeographed Study Prepared for the World Bank. Hanoi: Winrock International.

Lee, L. 1996. "Internally Displaced Persons and Refuges: Towards a Legal Synthesis." Journal of Refugee Studies 27:27 43.

Li, T.M. 2002. "Local Histories, Global Markets: Cocoa and Class in Upland Sulawesi.", Development and Change 33:415 37.

Luong, Q. and L.W. Tauer. 2006. "A Real Options Analysis of Coffee Planting in Vietnam." Agricultural Economics 35:49 57.

Minot, N. 1998. Competitiveness of Food Processing in Vietnam: A Study of the Rice, Coffee, Seafood and Fruit and Vegetables Subsectors. Washington, DC: International Food Policy Research Institute.

Müller, D. 2004. From Agricultural Expansion to Intensification: Rural Development and Determinants of Land Use Change in the Central Highlands of Vietnam. GTZ: Tropical Ecology Support Programme.

Nhan, D.T. 2001. "Orientations of Vietnam Coffee Industry." Speech given at the International Coffee Conference, May 17 19, London, UK. Retrieved November 14, 2003 (http://www.ico.org/event/wcc/nhan.pdf).

Oxfam. 2002. The Impact of the Global Coffee Trade on Dak Lak Province, Vietnam: Analysis and Policy Recommendations. Oxfam Great BritainOxfam Hong Kong: Information Centre for Agricultural and Rural Development.

Paterson, G. 1997. Traditional Resource Tenure and Livelihood Systems of Ethnic Minorities in Ratanakiri Province Cambodia: Responding to Rapid Change. Paper Presented at UNDP/ HPP/IMC Regional Workshop, April 8 10, Phnom Penh, NTFP Project in Ratanakiri.

Plant, R. 1994. Land Rights and Minorities. London: Minority Rights Group.

Potter, L. 2001. "Agricultural Intensification in Indonesia: Outside Pressures and Indigenous Strategies." Asia Pacific Viewpoint 42:305 17.

Rambo, T. 1995. The Challenges of Highland Development in Vietnam. Honolulu, HI: East West Center.

Rambo, T. and N. Jamieson. 2003. "Upland Areas, Ethnic Minorities, and Development." Pp. 139170 in Postwar Vietnam: Dynamics of a Transforming Society, edited by Hy V. Luong. Singapore: Institute of Southeast Asian Studies.

Robequain, C. 1939. Évolution Économique de l'Indochine Française. Paris: Hartmann. 
Saith, R. 2001. Social Exclusion: The Concept and Application to Developing Countries. Working Paper 27. Queen Elizabeth House, University of Oxford.

Salemink, O. 2003. The Ethnography of the Central Highlanders of Vietnam: A Historical Contextualization, 1850 1900. Honolulu, HI: University of Hawaii Press.

. 2000. "Customary Law, Land Rights and Internal Migration." Vietnam Social Sciences 76:65 79 .

Schrock, J.L. 1966. Minority Groups in the Republic of Vietnam. Washington, DC: American University Cultural Information Analysis Center.

Sen, A. 2000. 'Social Exclusion: Concept, Application, and Scrutiny.'” in Social Development Papers No. 1. Manila: Asian Development Bank, Office of Environment and Social Development.

Sikor, T. 2004. "Conflicting Concepts: Contested Land Relations in North Western Vietnam." Conservation and Society 2:75 96.

Sikor, T. and T.T.V. Pham. 2005. "The Dynamics of Commoditization in a Vietnamese Uplands Village, 1980 2000.” Journal of Agrarian Change 5:405 28.

Teulières, R. 1961. La Culture du Caféier au Sud Viêtnam. Bordeaux, France.

Thapa, G.B. 1998. "Issues in Conservation and Management of Forestation in Laos: The Case of Sangthong District." Singapore Journal of Tropical Geography 19:71 91.

Thompson, M. 2004. Root Shock. New York: Ballantine.

Thukral, E.G., ed. 1992. Big Dams, Displaced People. New Delhi: Sage Publications.

Tinh, V.X. 2002. Changing Land Policies and Its Impacts on Land Tenure of Ethnic Minorities in Vietnam. Hanoi: Institute of Ethnology, Retrieved March 15, 2005 from Community Based Management of Forestlands (http://www2.eastwestcenter.org/environment/ CBFM/Tinh2.pdf).

Van de Walle, D. and D. Gunewardena. 2001. "Sources of Ethnic Inequality in Vietnam." Journal of Development Economics 65:177 207.

Vandergest, P. 2003. "Land of Some Tillers: Development Induced Displacement in Laos.' International Social Science Journal 55:47 56.

Vandergeest, P., P. Idahosa, and P.S. Bose, eds. 2007. Development's Displacements: Ecologies, Economies, and Cultures at Risk. Vancouver: University of British Columbia Press.

Vietnam General Statistical Office. 1991. Vietnam's Statistical Yearbook. Hanoi: Statistical Publishing House.

World Bank. 2002a. "Vietnam at a Glance." Pp. 39 in From Agricultural Expansion to Intensification: Rural Development and Determinants of Land Use Change in the Central Highlands of Vietnam, edited by D. Muller. GTZ. Washington, DC: Tropical Ecology Support Programme, Retrieved January 11, 2007 (http://amor.cms.hu berlin.de/ muelleda/download/TOEB Report Daniel final.pdf).

. 2002b. Vietnam Development Report 2003: Delivering on its Promise. Vietnam Consultative Group Meeting. Washington, D.C.: The World Bank in Collaboration with the Asian Development Bank.

. 2002c. Vietnam Environment Monitor. Washington, DC: The World Bank.

. 2004. Vietnam: Coffee Sector Report, Vol. 1 of 1. Washington, DC: The World Bank.

Xuan, H. 1998. "The Impact of Rural Rural Migration to Resettlement Areas in Dak Lak Province.” Pp. 88104 in International Seminar on Internal Migration: Implications for Migration Policy in Vietnam. Population Council. 
Copyright of Rural Sociology is the property of Rural Sociological Society and its content may not be copied or emailed to multiple sites or posted to a listserv without the copyright holder's express written permission. However, users may print, download, or email articles for individual use. 